\section{DECONTAMINATION OF ELECTRICAL EQUIPMENT}

$7 \mathrm{HE}$ Government has published full instructions 1 for decontamination of electrical equipment, but, of necessity, these relate only to general conditions and do not deal in detail with the many specialized materials used by the electrical industry. In order to obtain more definite guidance on decontamination of equipment, the North Eastern Electrical Supply Co., Ltd., convened a committee to study this question. A report was submitted to the Ministry of Home Security and was amended according to its observations. The final report approved by the Ministry is now being issued by the Electricity Commission and should form a valuable guide to the industry.

After briefly reviewing the general principles of decontamination, the report states that there will be no immediate danger from the continued operation of contaminated plant, except in the case of bad contamination, when the electrical contamination of the plant itself may alter. There is, however, danger to personnel from the vapour which may arise from the contaminated gear if it becomes warm. The first action is directed towards removing the danger to personnel. Where it is impossible to shut down the plant to carry out complete decontamination, as much as possible should be done and danger notices should be placed on the remaining contaminated parts, with suitable ventilation provided to remove the vapour being given off. Successful decontamination is chiefly dependent on prompt application of the necessary treatment.

Insulating panels and metal can be cleaned by rags soaked in solvent and removing the excess solvent by clean rags. Sometimes solvents are effective. It is necessary in bad cases to strip the surface. Coils should be treated with solvents preferably sprayed on and afterwards wiped dry. In the case of electrical machines, they should be cleaned with solvents as much as possible, and then given a run at full load. The heat generated will vapourize any remaining liquid and so complete the decontamination. Adequate ventilation must be provided to remove the vapour and a gas inspection officer may be required before the plant can be declared free from contamination.

Lead-covered cables can be cleaned with solvents; but when the sheath is damaged the cable should be replaced. In the instructions the effect of blister gases on various insulating materials is shown in a lengthy table. In general, mustard gas penetrates a material, either by creeping along pores or fibres as in paper and brickwork, or by dissolving in the material as in bitumen, paraffin wax, otc. The firstmentioned class allows the gas to evaporate and can be affected by the destructive action of moisture on the gas. The latter class retains the gas for a long time, and only complete destruction is satisfactory. With regard to the type of solvent to be used, light oils have the advantage of being neither toxic nor inflammable. Paraffin is cheap and easily obtainable. A footnote is added to the report on the decontamination of areas affected by calcium arsenide. The most practical method is to hose the area liberally with water. This will at once liberate the arsine gas, which will be rapidly dispersed. Respirators must be worn but anti-gas clothing is unnecessary. On electrical apparatus the powder must be swept off and a blower used on the inaccessible places.

\section{FORTHCOMING EVENTS}

\author{
Tuesday, October 8
}

Institute of Fues (at the Connaught Rooms, Great Queen Street, London, W.C.2), at 2.15 p.m.-Mr. W. Boon : "Some Thoughts on Coke".

Illuminating Enginemerng Society (in the Lecture Theatre of the Royal Institution, 21 Albemarle Street, London, W.1), at 2.45 p.m.--Prof. J. T. MacGregor. Morris : "The Arc as a Standard of Light" (Presidential Address).

\section{APPOINTMENTS VACANT}

APPLICATIONS are invited for the following appointments on or before the dates mentioned:

TEACHER OF Mathematics, Physics and PHYSICAL TraIning at the Barnsley Mining and Technical College- The Principal, Technical College, Church Street, Barnsley (October 9).

DEPUTY BOROUGH EIECTRICAI ENGINEER-Mr. G. R. Spurr, Borough Electrical Engineer, Electric House, Church Hill, Walthamstow, E.17 (October 18).

DEPCTE ENGINEer AND MANAgFr of the Electrictity SUPPLY UNDERTARING-The Engineer and Manager, Elettricity Supply UNDERTARING-The Engineer and Manager, Electri
Department, Dewar Place, Edinburgh 3 (October 18).

Graddate Lectorer in EngineEring-The Principal, Wigan and District Mining and Technical College, Wigan.

Assistant ENGINEer for the DRAINAGE AND IRRIGamion DEPARTMENT, Malaya-The Crown Agents for the Colonies, 4 Millbank, London, S.W.1 (quoting M/9316).

Assistant Master for Generax Science and Mathrmatios at the Bath Technical College-The Director of Education, Education Department, Guildhall, Bath.

TEACHer of ENGINEERING (PRActical Mathematics, ENGINEERING DRAWING AND ENGINEERING ScIENCE) at the Falmouth Day Continuation and Technical School-The Clerk to the Governors, District Education Office, Falmouth.

\section{REPORTS AND OTHER PUBLICATIONS}

(not included in the monthly Books Supplement)

\section{Great Britain and Ireland}

Edinburgh and Fast of Scotland College of Agriculture. Calendar for 1940-1941. Pp. 66. (Edinburgh : Edinburgh and East of Scotland College of Agriculture.) $[249$ British Museum (Natural History). Economic Leaflets No. 4: Psocids, Book Lice, Dust Lice, etc. Pp. 4. $\frac{1}{2} d$. Economic Leaflets No. 5: Crickets. Pp. 4. 1d. (London: British Museum (Natural
History).)
[249

\section{Other Countries}

Bulletin of the American Museum of Natural History. Vol. 76, A.rt. 9: Lagomorpha and Rodentia other than Sciuridæ, Anomaluridæ and Idiuride, collected by the American Museum Congo Expedition. By Robert T. Hatt. Pp. 457-604+plates 7-19. Vol. 77, Art. 33 . A Revision of the Rotatorian Genera Brachionus and Platyias, with Descriptions of One New Species and Two New Varieties. By Elbert
H. Ahlstrom. Pp. 143-184+plates 2-20. Vol. 77, Art. 4: Studies H. Ahlstrom. Pp. 143-184+ plates 2-20. Vol. 77, Art. 4 : Studies on the Earliest Primates. By George Gaylord Simpson. Pp. 185-212.
(New York: American Museum of Natural History.) Imperial Council of Agricultural Research. Miscellaneous Bulletin No. 35: Progress of Veterinary Research in India during the Past Twenty-flve Years. By F. Ware. Pp. ii 37. (Delhi : Manager of Publications.) 1.2 rupees; $18.9 d$. Pp. It
[179

Records of the Botanical Survey of India. Vol. 5, No. 5 : Plants of the Lloyd Botanic Garden, Darjeeling. By Dr. K. P. Biswas. Pp. iv $+369-478$. 3.14 rupees ; 68 . $3 d$. Vol. 14, No. 1 A Revision of the Labiatæ of the Indian Empire. By Dr. S. K. Mukerjee. Pp. iv 1
$228+$ viii. 5 rupees ; 88. (Delhi: Manager of Publications.)
[179 New Zealand. Fourteenth Annual Report of the Department of Scientific and Industrial Research. Pp. 100. (Wellington: GovernScientific and Industrial Research. Pp. 100. (Wellington: Govern-
ment Printer.) 2s. Memoirs of the Geological Survey of India. Palseontologia Indica, New Series, Vol. 30, Memoir No. 1 : The Jurassic Brachiopoda of the Namyan Beds of the Northern Shan States, Burma. By Dr. M. $\mathbf{R}$. Sahni. Pp. v $+46+4$ plates. (Calcutta : Geological Survey of India.) 2.10 rupees; $48,3 d$.

Melk in het buzonder als Zingelingenvoedsel. Door Dr. J. He Haas an Ir. O. Meulemans. (Uit de Kinderklinik der Geneeskundige Hoogeschool te Batavia.) Pp. vii +104. (Batavia: M. Vervoort.)

Commonwealth of Australia : Council for Seientific and Industrial Research. Pamphlet No. 99: Studies on Chemical Weed-Killers with Special Reference to Skeleton Weed. By C. G. Greenham, Dr. G. A
Currie and F. F. Allan. Pp. 48. (Melbourne : Government Printer.) [259 